\title{
Auxiliary brood cell construction in nests of the stingless bee Plebeia lucii (Apidae: Meliponini)
}

\author{
Geisyane Franco da $\mathrm{Luz}^{1}$, Lúcio Antônio de Oliveira CAMPOs ${ }^{1}$, José Cola ZANUNCIO ${ }^{2}$, \\ José Eduardo SERRÃO ${ }^{1}$ \\ ${ }^{1}$ Departamento de Biologia Geral/BIOAGRO, Universidade Federal de Viçosa, Viçosa, Minas Gerais 36570-000, Brazil \\ ${ }^{2}$ Departamento de Entomologia/BIOAGRO, Universidade Federal de Viçosa, Viçosa, Minas Gerais 36570-000, Brazil
}

Received 1 November 2016 - Revised 15 March 2017 - Accepted 24 April 2017

\begin{abstract}
Queen production in stingless bees with fusion of neighboring brood cells occurs by the perforation of the adjacent brood cell or construction of an auxiliary one. This study describes the auxiliary brood cell building behavior in queenless colonies of Plebeia lucii. Queenright and queenless (orphan) colonies were monitored, and auxiliary cell construction was video-recorded in orphan colonies. Brood cells with auxiliary cells added were analyzed with X-rays to identify the amount of food and the larval behavior into the brood cells. Plebeia lucii had specific behavioral sequence in auxiliary cell building. The addition of auxiliary cells is the main strategy to produce queens in $P$. lucii, mainly for the production of emergency queens in orphan colonies because queen absence triggered a high production of auxiliary cells. X-ray analyses showed that auxiliary cell addition occurred when the food in the larval brood cells had been completely eaten and showed changes in dorsoventral position of the larvae. Larvae of males did not perforate auxiliary cells, indicating that sex-related factors affect this behavior. The wax handling by workers and the fused thin and concave-shaped wall between the auxiliary and larval brood cells seems to facilitate wall perforation by the larvae.
\end{abstract}

cell perforation / emergency queens / queen production / queenless colonies / stingless bees

\section{INTRODUCTION}

The survival of perennial colonies of bees depends on strategies to produce virgin queens (gynes) to ensure an egg-laying queen. Variable behaviors and physiological and genetic mechanisms are involved in this process. The different methods of queen production may be related to the large number of species and genera as well as to the ecological and life history variability of them (Engels and Imperatriz-Fonseca 1990; Hartfelder et al. 2006).

Electronic supplementary material The online version of this article (doi:10.1007/s13592-017-0513-7) contains supplementary material, which is available to authorized users.

Corresponding author: J. Serrão, jeserrao@ufv.brE.

Serrão, jeserrao@ufv.br

Manuscript editor: James Nieh
Stingless bees (Apidae: Meliponini) produce gynes throughout the year to replace the physogastric one and for swarming, but some of them may be killed by workers or remain caged in wax prisons (ImperatrizFonseca and Zucchi 1995; Ribeiro et al. 2003, 2006). Two queen production methods occur in Meliponini (Hartfelder et al. 2006): (i) queens and workers emerge from brood cells with similar sizes and caste determination occurs due to genetic and food quality differences (Engels and Imperatriz-Fonseca 1990; Jarau et al. 2010; Schwander et al. 2010) and (ii) larvae growing in brood cells with high food provision will become queens. The second mechanism occurs in species that build queen brood cells larger than those for workers, or when the larvae, after feeding on its provision, perforate a contiguous brood cell and consume additional available food (Engels and Imperatriz-Fonseca 1990; Hartfelder et al. 2006). 
Leurotrigona muelleri Friese (Apidae: Meliponini) larvae perforate any neighboring brood cell (Terada 1974), whereas Frieseomelitta varia Lepeletier and Tetragonula carbonaria Smith (Apidae: Meliponini) larvae perforate specific brood cells added by workers to the existing one. The added cell is termed "auxiliary cell," and in F. varia and T. carbonaria, it has no eggs, only food provisions consumed by the perforating larvae, and it occurs only in queenless colonies (Faustino et al. 2002; Nunes et al. 2015).

Plebeia lucii Moure (Apidae: Meliponini) is c.a. $3.0 \mathrm{~mm}$ long, and its brood cells are clustershaped (Moure 2004). Queen production in this specie by auxiliary cell addition was recorded in a previous study (Teixeira 2007). The objective of the present study was to describe for the first time the worker behavior in the construction of auxiliary cells for queen production in P. lucii .

\section{MATERIALS AND METHODS}

Plebeia lucii colonies were maintained at 24 to $28^{\circ} \mathrm{C}$ in wooden boxes covered with glass, for 7 months (September-October 2014 and JanuaryMay 2015), and with access to the external environment through a plastic tube. These colonies had food storage pots and brood cells in similar quantities with honey from Apis mellifera Linnaeus (Apidae: Apini) and pollen from F. varia and Friesella schrottkyi Friese supplied weekly.

The colonies were monitored daily, and once auxiliary cell construction was detected, it was recorded on video (Sony Handycam DCRDVD610 and DCR-TRV460 with magnifying lenses) at night shot mode.

\subsection{Queenright colonies—first phase of observations}

In the first step, seven colonies (A to $G$ ) were monitored for $8 \mathrm{~h}$ /day during 10 days. Cell construction and behavior of queens and workers in brood cells were video-recorded.

\subsection{Worker age}

After the first phase of observations, brood cells with pupae were removed from the colonies and kept in Petri dishes at 24 to $28{ }^{\circ} \mathrm{C}$. The emerged adult bees were labeled with non-toxic paint on the thorax to know how old the bees that build auxiliary cells are. Multiple age cohorts were color-marked per colony. The labeled bees were returned to their original colonies after queen removal (beginning of the second phase of observation).

\subsection{Queenless colonies-second phase of observations}

Queens were removed, and each queenless colony was monitored for $8 \mathrm{~h} /$ day for 50 days. Cell construction and worker oviposition were video-recorded. The removed physogastric queens were transferred to cages with workers of the same colony, from where new brood cells were produced and transferred to orphaned colonies without brood cells for possible addition of auxiliary cells.

\subsection{Data selection}

The data used in the descriptions were from four of the seven colonies, which had the higher number of auxiliary cell building.

\subsection{X-ray images}

Brood cells with auxiliary cells added were submitted to LX-60 X-rays and photographed with a digital camera (Faxitron X-ray Corp., Wheeling, IL) to identify the larva position in relation to the auxiliary cell construction site, the amount of food in the brood cell, and the larval behavior in brood cells with auxiliaries annexed.

\subsection{Behavioral descriptions}

Definitions, characterizations, and terminologies had not been made in previous work to the auxiliary cell building process. Here, we present a proposal to report this behavior in $P$. lucii using the provisioning and oviposition process (POP) descriptions in other stingless bee species. 


\section{RESULTS}

\subsection{Queenright colonies}

The video-record monitoring of the queenright colonies of $P$. lucii showed only the quiescent phase and provisioning and oviposition processes (POP) of brood cells. Auxiliary cells were produced, but their building processes were not reported because they were found completely constructed. Five queenright colonies had two auxiliary cells per completely built brood cell, which hampered observation of worker behavior during construction of the auxiliary cells. Queen brood cells were not found.

\subsection{Queenless colonies}

A total of 67 auxiliary cells were found in the queenless colonies. The average number of auxiliary cells in each colony was 12 ( $n=6$ colonies). The average period for the building of the first auxiliary cell was 3 days ( $n=7$ colonies) after queen removal.

The building of auxiliary cells in the queenless colonies occurred in the presence of free or caged gynes that emerged during the analyses.

The addition of new brood cells (brood cells produced in other cages with the removed physogastric queens) in queenless colonies stimulated building of new auxiliary cells when this had ceased for some days already.

\subsection{Age of workers}

Six- to 19-day-old workers and others of unknown age (unpainted) were found constructing auxiliary cells, with some of the painted bees being present from the onset building until brood cell operculation (sealing of cell by workers). A No color-marked bee of others' age was registered building an auxiliary cell.

\subsection{Behavioral descriptions}

The construction behavior for auxiliary cells (Online Resource 1) and its respective description and terminology was carried out from the observation of 11 auxiliary cells in the four queenless colonies (Table I; Figure 1). The total time for addition of the auxiliary cells varied according to colony from 3.59 to $18.92 \min (n=4$ colonies) (Table II).

Agglomeration Stage $(\overline{\mathrm{Ag}})$ was the first stage of the process, and it was characterized by workers' movement for nearly the entire cell surface. In the Construction Stage $(\overline{\mathrm{C}})$, the manipulation of the wax was characterized by two distinct moments: an initial forming the concavity which was the basis to auxiliary cell (Concavity Substage - $\overline{\mathrm{Cov}}$ ) followed by walls rising (Wall For-

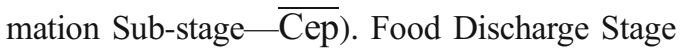
$(\overline{\mathrm{Da}})$ with Discharge $(\overline{\mathrm{da}})$ and Transition $(\overline{\mathrm{dt}}) \mathrm{Sub}$ stages were characterized by many worker body insertions into the auxiliary cell, and only the first four workers regurgitated food. In the Transition Sub-stage, the insertions overlapped with the operculation and oviposition. Oviposition Stage $(\overline{\mathrm{Oo}})$ was characterized by workers' oviposition inside the auxiliary cell with food, and it occurred in $27.27 \%(n=11)$ of these cells. In both auxiliary cells with eggs or no eggs, the other stages followed without changes. The last stage was the Operculation $(\overline{\mathrm{Op}})$ with Preoperculation $(\overline{\mathrm{Opp}})$ and Operculation $(\overline{\mathrm{op}})$ Sub-stages marked by the closure of the auxiliary cell by many workers side by side simultaneously (Online Resource 1).

The following atypical and rare behavior for auxiliary cell construction was observed: (i) construction was stopped at the Concavity Sub-stage or the beginning of Wall Formation; (ii) construction of two auxiliary cells, but one was subsequently destroyed while the other was completely added (Figure 2a); (iii) the auxiliary cell remained empty and closed; (iv) two auxiliary cells were completely added to the same brood cell (Figure 2b); (v) auxiliary cell depleted some days after construction; and (vi) auxiliary cell was built in the brood cell with male larva from worker egg. Each one of these atypical behaviors occurred one or two times among the 67 analyzed auxiliary cells.

\subsection{X-ray images}

X-ray analyses showed the anterior and posterior regions of the larvae and the position of the 
Table I. Auxiliary cell addition process (ACA) in queenless colonies of Plebeia lucii (Apidae, Meliponini) with their respective definitions, characterizations, and proposed terminologies

\begin{tabular}{|c|c|}
\hline SS & Definitions \\
\hline$\overline{\mathrm{Ag}}$ & $\begin{array}{l}\text { First activities in the cell to receive an auxiliary cell } \\
\text { generally characterized by a cluster of workers with } \\
\text { a high excitation degree, antennation behavior, and } \\
\text { movement for nearly the entire cell surface }\end{array}$ \\
\hline$\overline{\mathrm{C}}$ & $\begin{array}{l}\text { First visible wax manipulations and wall } \\
\text { construction } \\
\text { of the auxiliary cell }\end{array}$ \\
\hline$\overline{\operatorname{Cov}}$ & $\begin{array}{l}\text { Wax handling activity forming concavity to support } \\
\text { the auxiliary cell that resulted in a common wall } \\
\text { between cells as its own base was not built for the } \\
\text { auxiliary cell }\end{array}$ \\
\hline$\overline{\mathrm{Cep}}$ & Beginning of the wall formation of the auxiliary cell \\
\hline
\end{tabular}

$\overline{\mathrm{Da}}$

$\overline{\mathrm{da}} \quad$ Interval between the first discharge and the last body insertion into a cell (Fig. 1e)

$\overline{\mathrm{dt}} \quad$ Overlap of insertion behaviors, operculation, and oviposition by workers with body vibration during insertion

$\overline{\mathrm{Oo}}$
Oviposition Stage by workers (haploid eggs) in the auxiliary cell.
$\overline{\mathrm{Op}}$

$\overline{\mathrm{Opp}}$

$\overline{\mathrm{op}}$
Comments

Fig. 1a

Number of workers in construction begins from one to five and had two to five at the final stage $(n=10$ ACAs $)$

Transparency or color differences in the wax showed slight wall thinning (Fig. 1b)

Workers' number was proportional to the construction level and the final part with rapid worker replacements. At the beginning, one to five workers and at least two workers were at the end of the construction (Fig. 1c, d)

Contraction of the abdomen showed that the first four workers regurgitated food

High number of insertions in this sub-stage (32.82 $\pm 27.88,18-116 ; n=11$ ACAs) compared to that observed in the POP in the same colonies (min. $=3$, max. $=9,4.91 \pm 1.81$ worker inserts; $n=11$ observed POPs)

Figure 1f

Three cases were registered $(27.27 \%, n=11$ ACAs $)$ with one egg per cell. The other workers inserted the anterior body in the cell and touched the egg with antennas. There was oophagy (Fig. 1g). A worker remained with the egg attached to the abdomen and walked for $20 \mathrm{~s}$ until removing it with the front legs. In both auxiliary cells with eggs or no eggs, the other stages followed without changes

This occurred only once (19.64 s).

A worker begun operculation, but up to seven occurred until the end of the process. Auxiliary cell and $\mathrm{POP}$ operculation performed by various workers manipulating wax (Fig. 1h).

Agglomeration Stage $\overline{\mathrm{Ag}}$, Construction $(\overline{\mathrm{C}})$ with Sub-stages Concavity $(\overline{\mathrm{Cov}})$ and Wall Formations $(\overline{\mathrm{Cep}})$, Food Discharge Stage $(\overline{\mathrm{Da}})$ with Discharge $(\overline{\mathrm{da}})$ and Transition $(\overline{\mathrm{dt}})$ Sub-stages, Oviposition $(\overline{\mathrm{Oo}})$ and Operculation Stages $(\overline{\mathrm{Op}})$ with Preoperculation $(\overline{\mathrm{Opp}})$ and Operculation $(\overline{\mathrm{op}})$ Sub-stages. (SS): stages and sub-stages

- no comment

auxiliary cells in relation to these larval regions (Figure 3a). Larval movement was detected via images obtained at 3-min intervals (Figure 3c, d) and weekly (Figure 4) showing changes in 


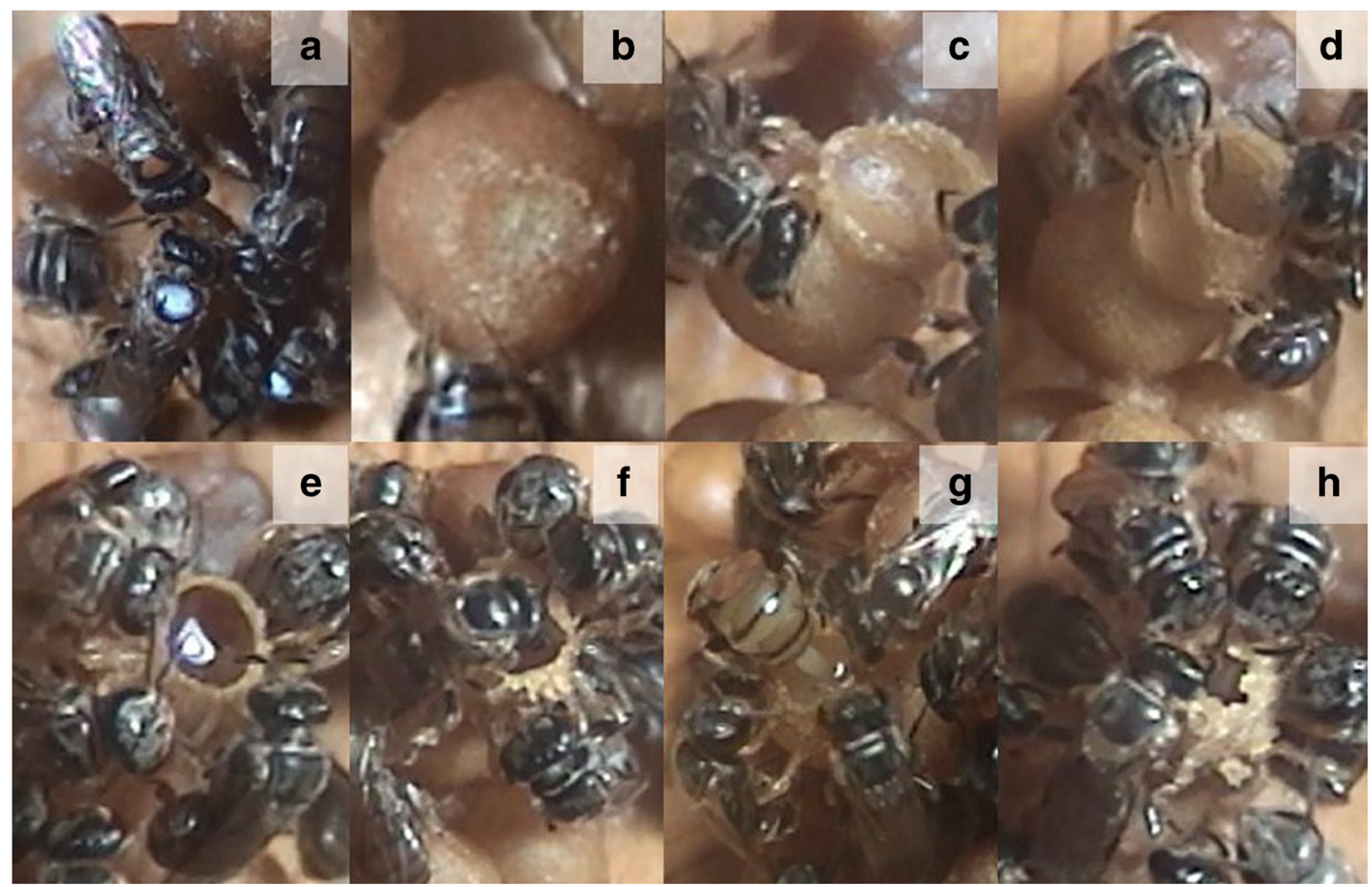

Figure 1. Auxiliary cell construction in queenless colonies of Plebeia lucii (Apidae: Meliponini). Agglomeration Stage (a); Construction with Sub-stages of Concavity (b ) and Wall Formations (c, d); Food Discharge with Substages of Discharge (e) and Transition (f); Oviposition (g); and Operculation (h).

dorsoventral position (Figure 4a, d), but few anteroposterior position movements. The larval head never moved to the position where the anus was formerly positioned. The larva in brood cell with two auxiliary cells only perforated one of them (Figure 3b). Auxiliary cells were added when there was no food in the larva brood cell (Figure 3e, f). Larvae from worker eggs cells (therefore male larvae) did not perforate the walls of the auxiliary cells (Figure 4).

\section{DISCUSSION}

Presence of auxiliary cells and absence of queen brood cells in $P$. lucii queenright colonies indicate the use of auxiliary cells as the only

Table II. Duration of events for auxiliary cell addition (ACA) in four queenless colonies of Plebeia lucii (Apidae; Meliponini)

\begin{tabular}{llllll}
\hline & $\overline{\mathrm{C}}(\mathrm{min})$ & $\overline{\mathrm{Da}}(\mathrm{s})$ & $\overline{\mathrm{Oo}}(\mathrm{s})$ & $\overline{\mathrm{op}}(\mathrm{min})$ & ACA (min) \\
\hline Minimum-maximum & $51.14-356.05$ & $59.53-861.40$ & $14.80-53.54$ & $2.25-15.11$ & $3.59-18.92$ \\
Mean & 113.42 & 187.77 & 31.57 & 4.95 & 6.53 \\
Standard deviation & 90.25 & 225.30 & 19.89 & 3.52 & 4.36 \\
Sample size & 10 & 11 & 3 & 11 & 11 \\
Sample variance & 8144.67 & $50,761.65$ & 395.53 & 12.42 & 18.98 \\
Standard error & 28.54 & 67.93 & 11.48 & 1.06 & 1.31 \\
\hline
\end{tabular}

$\bar{C}$ Construction Stage, $\overline{D a}$ Food Discharge Stage, $\overline{O o}$ Oviposition Stage (by workers), $\overline{O p}$ Operculation Sub-stage, $A C A$ total duration process of auxiliary cell addition, s seconds, min minutes 


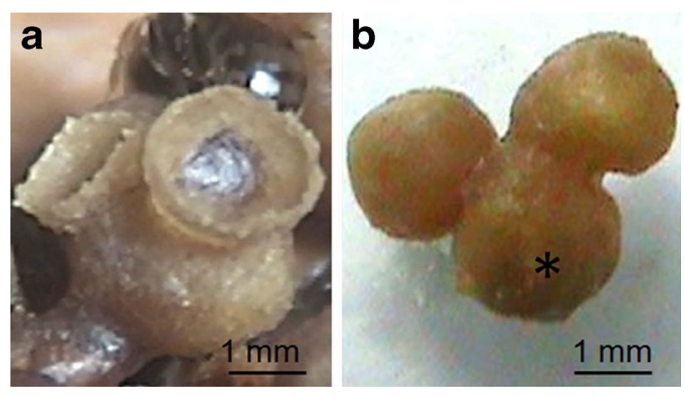

Figure 2. Atypical auxiliary cell construction in queenless colonies of Plebeia lucii (Apidae: Meliponini). a Brood cell with two auxiliary cells in construction. b Brood cell (asterisk) with two auxiliary cells added.

strategy to produce queens, corroborating previous findings (Teixeira 2007). Tetragonula carbonaria build auxiliary cells only in queenless colonies and after changes in the brood comb design (Nunes et al. 2015).

The high number of auxiliary cells in $P$. lucii queenless colonies suggests that queen absence triggers the production of emergency queens, as reported for $A$. mellifera, $F$. varia, and T. carbonaria (Fell and Morse 1984; Faustino et al. 2002; Nunes et al. 2015). Unlike Apis spp., stingless bees produce gynes throughout the year (Michener 1974; Imperatriz-Fonseca and Zucchi 1995; Ferreira et al. 2013) with larvae receiving mass provisioning in the brood cell closed throughout its development (Michener 1974). These factors support the absence of production of emergency queens in Meliponini, which decreases the chances of colony survival when there are no gynes available for replacement. Production of queens using auxiliary cells is an alternative to those rare conditions and, at least for P. lucii and T. carbonaria (Nunes et al. 2015), allows reproduction management in artificial colonies (Jaffé et al. 2015).

Production of 12 auxiliary cells per colony of $P$. lucii in queenless conditions, even in the presence of gynes, suggests that the production of new queens is a priority with a trade-off in the production of new queens with worker losses because worker larvae develop into queens and only one of them will be established in the colony. This may reduce the population and weaken the colony due to stopping construction of new worker brood cells. Frieseomelitta varia adds auxiliary cells at 8 to 13 days after queen removal (Faustino et al. 2002); however, under field conditions it cannot be ruled out that a queen might be replaced by another, avoiding the production of emergency ones.

The addition of new auxiliary cells after transferring new brood cells in $P$. lucii colonies suggests that brood cell availability for larvae development may be the limiting factor for the production of emergency queens. For F. varia (Faustino et al. 2002), the availability of young larvae is a stimulus for the construction of auxiliary cells, and in A. mellifera the destiny of larvae as either worker or queen is determined from the third day of development (Fell and Morse 1984).

Worker reproduction does not seem to be a stimulus for the construction of auxiliary cells in $P$. lucii because these workers did not lay eggs in queenright colonies and it was uncommon for eggs to be laid in auxiliary cells in queenless ones. Melipona bicolor (Apidae, Meliponini) workers that lay eggs are specialized in the construction of brood cells (Cepeda 2006).

In stingless bee colonies, the workers' labor division is closely related to the bee ages following an ontogenetic sequence of activities (age polyethism). Plebeia lucii workers that build auxiliary cells in queenless colonies are young, similar to labor division in queenright colonies, with younger workers performing brood care (Michener 1974; Cepeda 2006; Giannini 1997). The age of P. lucii workers building auxiliary cells was similar to that reported for Scaptotrigona postica Latreille (10 to 20 days) and Plebeia remota Holmberg (Apidae: Meliponini) (12 to 24 days) in brood cell construction (Sakagami and Zucchi 1963; van Benthem et al. 1995).

The site for auxiliary cell addition and the concavity formation $(\overline{\mathrm{Cov}})$ are important steps for the success of wall perforation by larvae. The choice of auxiliary cell addition site may be performed in the Agglomeration Stage $(\overline{\mathrm{Ag}})$ before any wax is manipulated. The typical activities of this stage (high excitation degree, antennation, and movement for nearly the entire cell surface) may be important for detection of the cell region which is the larval head. Rare construction errors in places near the posterior larval region may hamper access to the auxiliary cells. The 


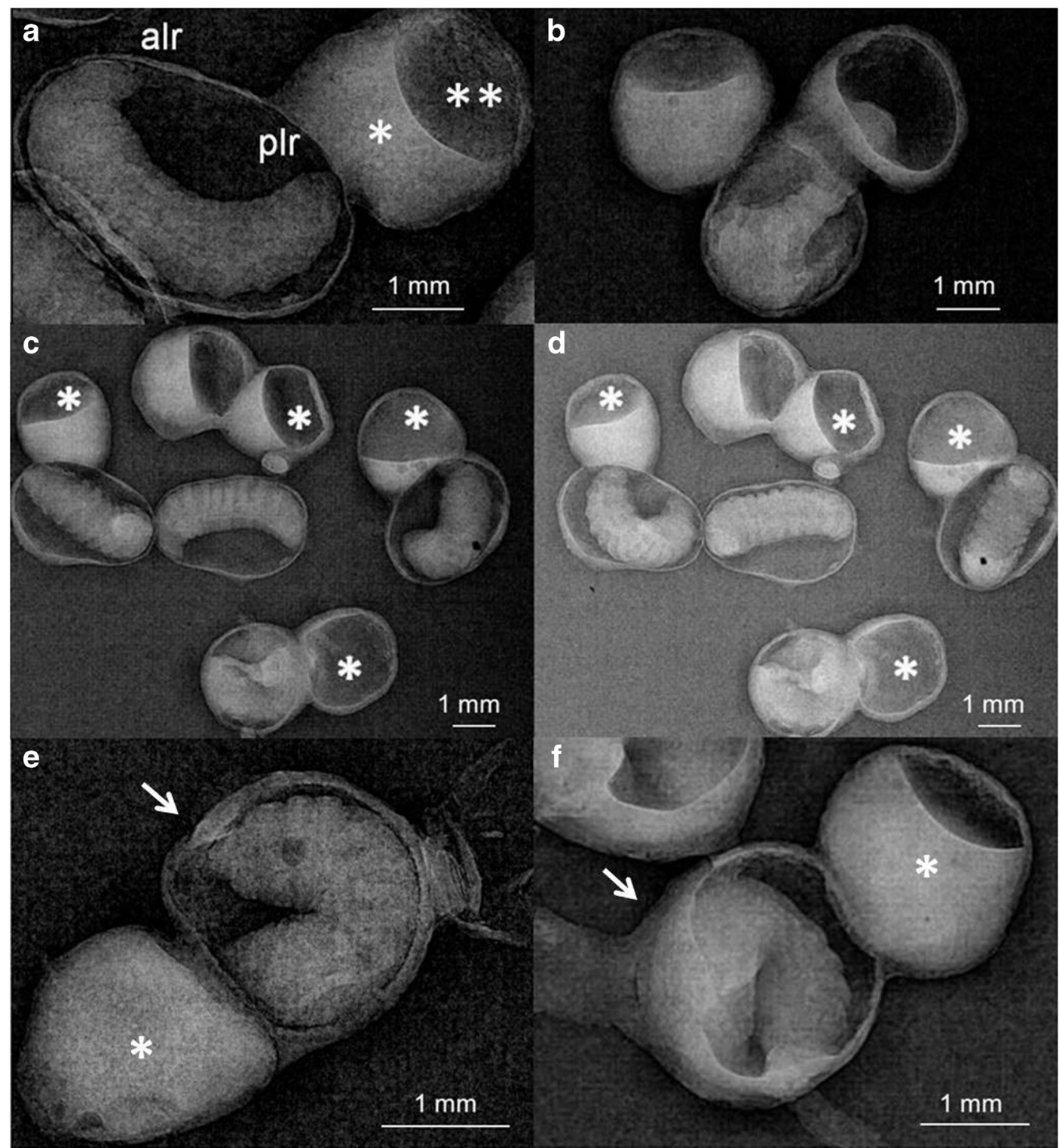

Figure 3. X-ray images of brood and auxiliary cells in queenless colonies of Plebeia lucii (Apidae: Meliponini). a Anterior (alr) and posterior (plr) larval regions. b Brood cell with two auxiliary cells, and a larva-perforating one. c, d Images with 3-min intervals showing larvae position changes within the cell. e, f Images obtained immediately after the addition of auxiliary cell showing larval cell (arrows) without food. Asterisk, auxiliary cells. Double asterisks, air space.

construction of two auxiliary cells may be a correction of the construction in the wrong place, which is reinforced by the larva perforating only one of the available cells. The wax handling and the common wall between the auxiliary and larval brood cells, which is thin and concave-shaped, may facilitate wall perforation by the larvae.
Larvae of males did not perforate auxiliary cells, indicating that sex-related factors affect this behavior.

Plebeia lucii did not build the "feeding connection" (hole connecting the brood and auxiliary cells from which the larvae access the additional food) that was observed in $F$. varia 


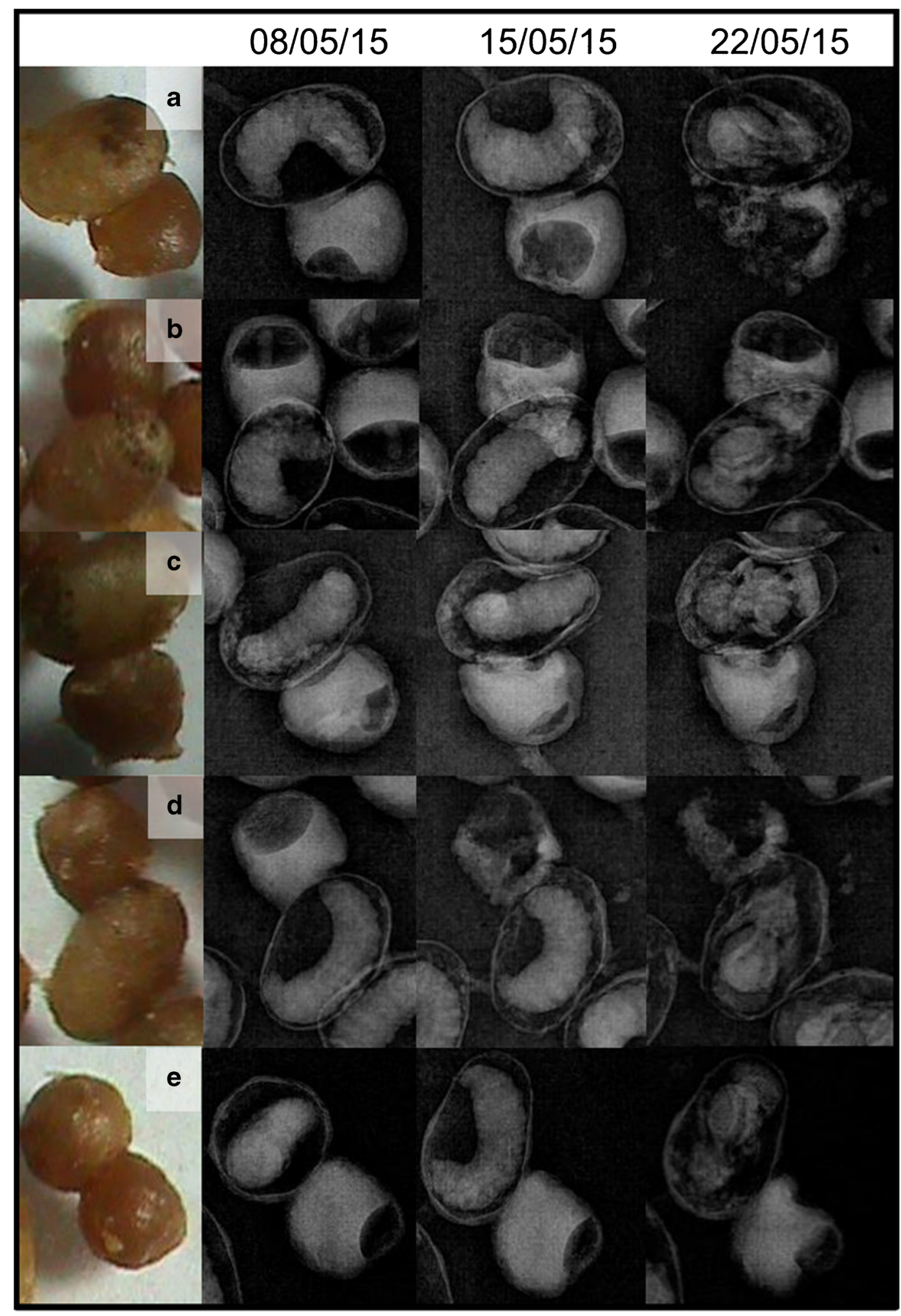


4 Figure 4. X-ray images of brood cells with auxiliary ones with larvae from worker eggs in Plebeia lucii (Apidae: Meliponini). Images obtained weekly showing larval development and position. Note that auxiliary cells are not perforated and larval movement with change of the dorsal and ventral regions $(\mathbf{a}, \mathbf{d})$.

(Faustino et al. 2002) because the two cells already have a common wall.

The duration of regurgitation in the auxiliary cell was higher than in the POP, probably due to lack of limitation from a queen, which decreases the duration of the discharge because it remains fixed in the brood cell and inserts its body rapidly after a few regurgitations by the workers and with the Transition Stage $(\overline{\mathrm{dt}})$ with workers preventing the operculation.

The auxiliary cell operculation by $P$. lucii is similar to that of $F$. schrottkyi with several workers manipulating the wax laterally with the head facing the cell aperture (Sakagami et al. 1973) without the worker body rotation typical of other Plebeia species (Drumond et al. 2000).

The elaborate and specialized auxiliary cell addition process in P. lucii differs from neighboring cell perforation in L. muelleri and from addition in F. varia and T. carbonaria (Terada 1974; Faustino et al. 2002; Nunes et al. 2015). The homology of larvae brood cell perforation behavior has been based on the common origin of queen cell construction in stingless bees (Nunes et al. 2015). However, it is likely that perforation behavior has an independent origin as seen via interspecific differences and its occurrence in phylogenetically distinct taxa (Faustino et al. 2002) such as Plebeia, Leurotrigona, Frieseomelitta, and Tetragonula (Rasmussen and Cameron 2010).

Plebeia lucii and F. varia have brood cells in cluster, whereas $T$. carbonaria has disc brood cells. The occurrence of auxiliary cells would be facilitated in species with nest architecture of brood cells with some distance among them, whereas in closely associated ones space for addition of a new cell would be not available. In this sense, $T$. carbonaria use auxiliary cells only in queenless colonies in which the brood comb changes for an irregular architecture with space among cells (Nunes et al. 2015).

The mechanisms for the selection of larvae that will receive an auxiliary cell are unknown for $P$. lucii. The absence of direct contact between larvae and workers in stingless bees may hamper possible larval selection contrary to findings for A. mellifera. In this species, larval selection can be based on genotypes with a low frequency in the colony (Moritz et al. 2005) and sister larvae (preferably patrilineal) to increase their inclusive fitness (Châline et al. 2003) for production of emergency queens. In $P$. lucii, the occurrence of auxiliary cells with interrupted construction raises questions regarding the stimuli to attract or signal workers to build them. The construction in brood cells with larvae from worker eggs indicates that the stimuli may be from both male and female larvae. Larval defecation may limit auxiliary cell addition, because these larvae do not feed anymore (Michener 1974; Weiss 2006) and will not develop in a queen. This finding suggests that workers recognize some possible signal from defecating larvae and avoid addition of auxiliary cells, but the signals remain unknown for sure.

Larvae from worker eggs do not perforate auxiliary cells, indicating a possible dimorphism between male and female larvae. Morphological and behavioral differences in larvae are rare in bees, but have been reported for Anthophora occidentalis Cresson (Apidae: Anthophorini) (Nielsen and Bohart 1967), Coelioxys sp. Latreille (Megachilidae: Megachilini) (Baker 1971), and S. postica (Beig 1972).

Queen production in $P$. lucii by auxiliary cell addition was suggested in previous studies in which the concavity and common brood cell walls were described (Teixeira 2007). We report that the construction of auxiliary cells for queen production in queenless colonies of $P$. lucii shows specialized and elaborate behavioral sequences. High production of auxiliary cells in queenless conditions of $P$. lucii suggests that the production of new queens is a priority despite the high worker trade-off when population is reduced due to POP stopping. 


\section{ACKNOWLEDGMENTS}

We thank Apiário Central of Universidade Federal de Viçosa for bee colonies and laboratory structure and the Laboratório de Ecotoxicologia of Universidade Federal de Viçosa for the availability of the radiography system. Weyder Cristiano Santana is acknowledged for his valuable suggestions and support during the various stages of the project. We acknowledge financial support by Coordenação de Aperfeiçoamento de Pessoal de Nível Superior.

Contributions GFL and JES conceived this research and designed experiments; GFL performed the experiments and analysis; GFL, JES, and LAOC analyzed and interpreted the data. GFL, JES, and JCZ wrote the paper.

\section{ANNEX}

\section{Movie files available in Online supplementary material}

Video records of auxiliary cell addition behavior in queenless colonies of Plebeia lucii (Apidae: Meliponini). Examples of Agglomeration, Construction (Concavity and Wall Formations Sub-stages), Food Discharge (Discharge and Transition Sub-stages), Oviposition (by workers) and Operculation (Operculation Sub-stage) Stages are available. Oviposition Stage was characterized by workers laying inside the auxiliary cell with food in $27.27 \%(n=11)$ of these cells. In both auxiliary cells with eggs or not eggs, the other stages followed without changes.

Construction de cellules de couvain auxiliaires dans les nids de l'abeille sans aiguillon Plebeia lucii (Apidae: Meliponini)

perforation de la cellule / émergence des reines / production de reine / colonies orphelines

Der Bau erweiterter Brutzellen in Nestern der stachellosen Biene Plebeia lucii (Apidae: Meliponini)

Brutzelldurchbohrung / Ersatzköniginnen / Könignnenproduktion/weisellose Kolonien / stachellose Bienen

\section{REFERENCES}

Baker, R. (1971). Development and sexual dimorphism of larvae of the bee genus Coelioxys. J. Kans. Entomol. Soc. 44 (2), 225-235.

Beig, D. (1972). The production of males in queenright colonies of Trigona (Scaptotrigona) postica. J. Apic. Res. 11 (1), 33-39.

Cepeda, O. I. (2006). Division of labor during brood production in stingless bees with special reference to individual participation. Apidologie, 37 (2), 175-190.

Châline, N., Ratnieks, F. L. W., Arnold, G., Papin, C. (2003). Patriline differences in emergency queen rearing in the honey bee, Apis mellifera. Insectes Soc. 50 (3), 234-236.

Drumond, P. M, Zucchi, R., Oldroyd, B. P. (2000). Description of the cell provisioning and oviposition process of seven species of Plebeia Schwarz (Apidae, Meliponini), with notes on their phylogeny and taxonomy. Insectes Soc. 47 (2), 99-112.

Engels, W., Imperatriz-Fonseca, V. L. (1990). Caste development, reproductive strategies, and control of fertility in honey bees and stingless bees, in: Engels, W. (Ed.), Social Insects-An evolutionary approach to castes and reproduction. Springer-Verlag, Berlim, pp. 167230.

Faustino, C. D., Silva-Matos, E. V., Mateus, S., Zucchi, R. (2002). First record of emergency queen rearing in stingless bees. Insectes Soc. 49 (2), 111-113.

Fell, R. D., Morse, R. A. (1984). Emergency queen cell production in the honey bee colony. Insectes Soc. 31 (3), 221-237.

Ferreira, N. T., Blochtein, B., Serrão, J. E. (2013). Seasonal production and spatial distribution of Melipona bicolor schencki (Apidae; Meliponini) castes in brood combs in southern Brazil. Apidologie 44 (2), 176-187.

Giannini, K. M. (1997). Labor division in Melipona compressipes fasciculata Smith (Hymenoptera: Apidae: Meliponinae). An. Soc. Entomol. Brasil 26 (1), 153-162.

Hartfelder, K., Makert, G. R., Judice, C. C., Pereira, G. A. G., Santana, W. C., et al. (2006). Physiological and genetic mechanisms underlying caste development, reproduction and division of labor in stingless bees. Apidologie 37 (2), 144-163.

Imperatriz-Fonseca, V. L., Zucchi, R. (1995). Virgin queens in stingless bee (Apidae, Meliponinae) colonies: a review. Apidologie 26 (3), 231-244.

Jaffé, R., Pope, N., Carvalho, A. T., Maia, U. M., Blochtein, B., et al. (2015). Bees for Development: Brazilian Survey Reveals How to Optimize Stingless Beekeeping. PLoS One 10 (3), e0121157.

Jarau, S., van Veen, J. W., Twele, R., Reichle, C., Gonzales, E. H., et al. (2010). Workers make the queens in Melipona bees: identification of geraniol as a caste determining compound from labial glands of nurse bees. J. Chem. Ecol. 36 (6), 565-569. 
Michener, C. D. (1974). The social behavior of the bees. Harvard University Press, Cambridge.

Moritz, R. F., Lattorff, H. M. G., Neumann, P., Kraus, F. B., Radloff, S. E., Hepburn, H. R. (2005). Rare royal families in honeybees, Apis mellifera. Naturwissenschaften 92 (10), 488-491.

Moure, J. S. (2004). Duas novas espécies de Plebeia Schwarz do Brasil (Hymenoptera, Apidae, Meliponinae). Rev. Bras. Ent. 48 (2), 199-202.

Nielsen, R. A., Bohart, G. E. (1967). Sex characters of larval bees (Hymenoptera: Apoidea). Ann. Ent. Soc. Am. 60 (2), 414- 419.

Nunes, T. M., Heard, T. A., Venturieri, G. C., Oldroyd, B. (2015). Emergency queens in Tetragonula carbonaria (Smith, 1854) (Hymenoptera: Apidae: Meliponini). Aust. Entomol. 54 (2), 154-158.

Rasmussen, C., Cameron, S. A. (2010). Global stingless bee phylogeny supports ancient divergence, vicariance, and long distance dispersal. Biol. J. Linn. Soc. 99 (1), 206-232.

Ribeiro, F. M., Imperatriz-Fonseca, V. L., Santos-Filho, P. S. (2003). Exceptional high queen production in the Brazilian stingless bee Plebeia remota. Stud. Neotrop. Fauna Environ. 38 (2), 111-114.

Ribeiro, M. F., Wenseleers, T., Santos Filho, P. S., Alves, D. A. (2006). Miniature queens in stingless bees: basic facts and evolutionary hypotheses. Apidologie 37 (2), 191-206.

Sakagami, S. F., Zucchi, R. (1963). Oviposition process in a stingless bee, Trigona (Scaptotrigona) postica Latr. (Hym.). Stud. Ent. 6 (4), 497-510.

Sakagami, S. F, Camilo, C., Zucchi, R. (1973). Oviposition behavior of a Brazilian stingless bee, Plebeia (Friesella) schrottkyi, with some remarks on the behavioral evolution in stingless bees. J. Fac. Sci. Hokkaido Univ. 19 (1), 163-187.

Schwander, T., Lo, N., Beekman, M., Oldroyd, B. P., Keller, L. (2010). Nature versus nurture in social insect caste differentiation. Trends Ecol. Evol. 25 (5), 275-282.

Teixeira L. V. (2007) Produção de rainhas em colônias de Plebeia lucii (Hymenoptera, Apidae, Meliponina). Master thesis, Programa de Pós-graduação em Entomologia, Universidade Federal de Viçosa, Viçosa.

Terada, Y. (1974). Contribuição ao estudo da regulação social em Leurotrigona muelleri e Frieseomelitta varia (Hymenoptera, Apidae). $\mathrm{PhD}$ thesis, Universidade de São Paulo, Ribeirão Preto, Brasil.

Van Benthem, F. D. J., Imperatriz-Fonseca, V. L., Velthuis, H. H. W. (1995). Biology of the stingless bee Plebeia remota (Holmberg): observations and evolutionary implications. Insectes Soc. 42 (1), 71-87.

Weiss, M. R. (2006). Defecation behavior and ecology of insects. Annu. Rev. Ent. 51 (1), 635-61. 